\title{
"A longitudinal study of corporate social responsibility expenditure and ownership structure of financial firms"
}

\begin{tabular}{|c|c|}
\hline AUTHORS & $\begin{array}{l}\text { Md. Abu Jahid (D) } \\
\text { Md. Harun Ur Rashid (D) } \\
\text { Md. Abdul Kaium Masud (iD) } \\
\text { R } \\
\text { Rizal Yaya (D) }\end{array}$ \\
\hline ARTICLE INFO & $\begin{array}{l}\text { Md. Abu Jahid, Md. Harun Ur Rashid, Md. Abdul Kaium Masud and Rizal Yaya } \\
\text { (2022). A longitudinal study of corporate social responsibility expenditure and } \\
\text { ownership structure of financial firms. Banks and Bank Systems, 17(1), 24-37. } \\
\text { doi:10.21511/bbs.17(1).2022.03 }\end{array}$ \\
\hline DOI & http://dx.doi.org/10.21511/bbs.17(1).2022.03 \\
\hline RELEASED ON & Friday, 28 January 2022 \\
\hline RECEIVED ON & Sunday, 24 October 2021 \\
\hline ACCEPTED ON & Friday, 14 January 2022 \\
\hline LICENSE & $\begin{array}{l}(c) \text { EY } \\
\text { This work is licensed under a Creative Commons Attribution } 4.0 \text { International } \\
\text { License }\end{array}$ \\
\hline JOURNAL & "Banks and Bank Systems" \\
\hline ISSN PRINT & $1816-7403$ \\
\hline ISSN ONLINE & $1991-7074$ \\
\hline PUBLISHER & LLC "Consulting Publishing Company "Business Perspectives" \\
\hline FOUNDER & LLC "Consulting Publishing Company "Business Perspectives" \\
\hline
\end{tabular}

NUMBER OF REFERENCES

38

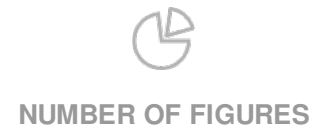

0
NUMBER OF TABLES

6

(C) The author(s) 2022. This publication is an open access article. 


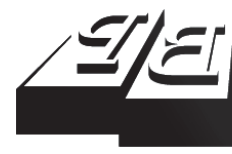

\section{BUSINESS PERSPECTIVES}

LLC "CPC "Business Perspectives" Hryhorii Skovoroda lane, 10, Sumy, 40022, Ukraine www.businessperspectives.org
Received on: $24^{\text {th }}$ of October, 2021 Accepted on: $14^{\text {th }}$ of January, 2022 Published on: $28^{\text {th }}$ of January, 2022

(c) Md. Abu Jahid, Md. Harun Ur Rashid, Md. Abdul Kaium Masud, Rizal Yaya, 2022

Md. Abu Jahid, Post Graduate Program Lecturer, Faculty of Economics and Business, Universitas Muhammadiyah Yogyakarta, Indonesia.

Md. Harun Ur Rashid, MBA, Faculty of Accounting, Department of Economics and Banking, International Islamic University Chittagong, Bangladesh.

Md. Abdul Kaium Masud, PhD, Associate Professor, Faculty of Business Administration, Department of Business Administration, Noakhali Science and Technology University, Bangladesh. (Corresponding author)

Rizal Yaya, PhD, Professor, Faculty of Economics and Business, Universitas Muhammadiyah Yogyakarta, Indonesia.

This is an Open Access article, distributed under the terms of the Creative Commons Attribution 4.0 International license, which permits unrestricted re-use, distribution, and reproduction in any medium, provided the original work is properly cited.

Conflict of interest statement: Author(s) reported no conflict of interest
Md. Abu Jahid (Indonesia), Md. Harun Ur Rashid (Bangladesh), Md. Abdul Kaium Masud (Bangladesh), Rizal Yaya (Indonesia)

\section{A LONGITUDINAL STUDY OF CORPORATE SOCIAL RESPONSIBILITY EXPENDITURE AND OWNERSHIP STRUCTURE OF FINANCIAL FIRMS}

\begin{abstract}
There is a dearth of longitudinal studies of corporate social responsibility expenditure (CSRE) and corporate governance in Bangladesh, which has been the impetus for this study. The study aims to identify the relationship between ownership structure and CSR expenditure. The empirical study considered a longitudinal period of 2007-2019 of listed financial firms (banks and non-banking financial institutions) of Bangladesh. The final sample consisted of 461 firm-year observations for 53 firms. The study incorporated a set of theories, including agency cost theory and stakeholder theory. The study applied the ordinary least square (OLS) regression technique to test hypotheses. The results of multiple regression analysis showed that foreign ownership and managerial ownership contribute positively and significantly to CSRE. However, the study did not document any relationship between institutional ownership and CSRE. The study used rigorous and alternative measurement techniques to further verify the findings. It was concluded that value creation from CSRE is highly dependent on the ownership structure of financial firms. The empirical study has significant theoretical and managerial implications.
\end{abstract}

\section{Keywords \\ CSR expenditure, corporate governance, ownership structure, banks, Bangladesh}

\section{JEL Classification $\quad$ G21, G23, G32, G38, O16}

\section{INTRODUCTION}

The nature of CSR and environmental investment and expenditure largely depends on the top management priority; it is also more evident when the sample consists of developing countries. Investors are the most influential part of any organization to take any sort of decision. Not only investment, but also routine business management decisions depend on the corporate policy pursued by different shareholders and investors. The monetary decision of CSR mostly depends on the corporate governance elements. Stakeholder engagement and regulatory compliance also influenced CSR expenditure decisions. Firms in developing countries face limited stakeholder pressure, and there is also a lack of regulatory compliance (Bae et al., 2018, 2021; Rashid, 2021; Bose et al., 2020a; Masud et al., 2019, 2018a, 2018b, 2017). In the presence of weak corporate governance, the financial system of emerging countries like Bangladesh has a conflict between shareholders and agents due to the benefits and short-term investment decisions. It is essential to examine whether the stakeholders and agency theory are the best approach to explain the relationship between ownership structures and CSR expenditure. 
Most of CSR studies highly focused on disclosure performance (non-financial) rather than monetary-based performance (financial). The prior study used content analysis and third-party rating to evaluate the CSR performance of firms. Nevertheless, the non-monetary nature of content-based disclosure and rating are not enough to measure the monetary-based CSR performance of firms (Bose et al., 2020b). The most recent study by Khan et al. (2021) raised the issue of 'green washing' or 'authenticity effort' of the sustainability reporting quality of financial firms. CSR expenditure is considered a value-driven approach that allures management to invest more in CSR activities to inform various stakeholders (Bose et al., 2020b). Khan et al. (2021), Bose et al. (2020b), and Bhattacharyya and Rahman (2020) empirically proved that CSR expenditure enhances firm growth, stability, and quality of information because of high-value creation and keeping the commitment. As already mentioned, most of CSR research focused on non-financial performance measurement rather than financial attributes. Prior studies of Khan et al. (2021), Bose et al. (2020b), Bhattacharyya and Rahman (2020), Feng et al. (2015), Manchiraju and Rajgopal, (2017), Dharmapala and Khanna (2018), Kapoor and Dhamija, (2017), and Brammer and Millington (2008) have examined the actual CSR expenditure performance of firms. Furthermore, the above mentioned actual CSR expenditure studies examined market value (Bose et al., 2020b), stock return (Bhattacharyya \& Rahman, 2020), quality information of sustainability reporting (Khan et al., 2021), shareholder value (Manchiraju \& Rajgopal, 2017), CSR compliance (Dharmapala \& Khanna, 2018; Kapoor \& Dhamija, 2017). No study considered the impact of actual CSR expenditure on corporate governance. This study was undertaken as an attempt to fill this literature gap.

The study is designed to ask a question under what circumstances corporate governance element (ownership structure) decides to use CSR expenditure. To explore the research question based on the literature gap, the study is designed to investigate the extent of the ownership structure impact on CSR expenditure. To the authors' knowledge, this is the first study that considers CSR expenditure to evaluate the relationship between ownership structure and CSR expenditure. Bangladesh has recently entered into the list of developing countries. Its financial sector is now booming and undergoing expansion, with several local and international banking institutions involved in the field. As new banks are permitted to enter Bangladesh's financial market, competition in the banking sector has intensified over time. It is also expected that future competition between public and private banks will be fierce (Rahman et al., 2021). Moreover, the grounds for considering Bangladeshi financial firms are as follows:

1) the financial sector is the most regulated in the country compared to the non-financial sector (Bae et al., 2021);

2) the central bank of the country promulgated CSR regulation since 2008 for the financial sector that ensures availability of CSR expenditure data of financial sector;

3) Bangladesh is the most emerging economy in the world, while CSR expenditure is very helpful to mitigate poverty alleviation (World Bank, 2017), along with the achievement of remarkable progress on the Sustainable Development Goals (SDGs).

To investigate the relationship between ownership structure and CSR expenditure, the study incorporated a set of hypotheses, including listed financial sector firms of Bangladesh. Finally, the study documented 461 firm-year observations during 2007-2019. 


\section{THEORETICAL DISCUSSION, LITERATURE REVIEW AND HYPOTHESIS DEVELOPMENT}

Sound governance inspires CSR performance to mitigate internal and external limitations and promote business expansion. Corporate governance elements contribute significantly to investing in social and environmental projects, abstaining from unethical practices, mitigating social legitimacy, reporting sustainable information, and increasing growth. Prior literature already evidenced the impact of the corporate governance elements of these issues (Bae et al., 2018, 2021; Masud et al., 2018a, 2019; Khan et al., 2013). Moreover, both developed and developing countries are seeing an increase in the number of corporate sustainability studies (Rashid, 2021; Khan et al., 2021; Bose et al., 2020a).

\subsection{Theory formulation and CSRE}

Prior study of CSR investment, CSR performance, CSR disclosure, and corporate governance extensively used several theories, including agency theory, resource dependency theory, resource-based view, intuitional theory, legitimacy theory, signaling theory, and stakeholder theory (Oh et al., 2011; Harjoto \& Laksmana, 2016). Most recent research on CSR investment and corporate governance explored the importance of ownership and board characteristics elements in the CSR investment decisions (Bae et al., 2018, 2021; Rahman et al., 2021; Khan et al., 2013, 2020; Jahid et al., 2020; Masud et al., 2018a). Based on the prior literature, the study used agency cost and stakeholder's theoretical approach to best explain the relationship between CSR expenditure and corporate governance from an emerging economy perspective (Bae et al., 2018; Masud et al., 2018a). The study uses ownership structures prominently influenced by the CSR expenditure decision. The study incorporated agency theory to explain the research framework because agency conflicts have a significant impact on the CSR decision (Rashid et al., 2021; Oh et al., 2011; Harjoto \& Laksmana, 2016). In general, there is a conflict between an owner and an agent because of the benefits and short-term nature of investment decisions. To avoid these conflicts, shareholders can work to develop a pos- itive reputation for their independence from management, management guidance, and work ethic (Rashid et al., 2021). At the same time, a board can monitor top management policy, regulation, and implementation regarding CSR expenditure and investment. Therefore, monitoring and controlling board activities mitigate agency conflict and enhance board CSR performance. CSR expenditure delivers a powerful message to a variety of stakeholders, reducing agency conflict and ensuring management commitment to long-term development.

Stakeholder theory promotes the relationship between business and different interested groups, including customers, lenders, suppliers, workers, government, local authority, environmental groups, non-government organizations, civil society, pressure groups, and media. The success of an organization mostly depends on the effective engagement of stakeholders. A stakeholder argues any issue that is non-favorable to the society and environment. On the other hand, a satisfied stakeholder can be used as a brand ambassador. To mitigate any social threats and detrimental functions of the business, CSR expenditure can be used as an important weapon. Moreover, higher CSR expenditure sends a commitment and faithful signal to the market that enhances a firm's visibility and reputations. Under the stakeholder theoretical lens, CSR expenditure enhances corporation market-based value along with restoring reputation (Khan et al., 2021; Bose et al., 2020b). Furthermore, experienced and expert stakeholder group suggestion helps management to ensure effective and timely decisions on a particular issue. In modern times, stakeholder engagement is treated as a winwin situation for both the business and a particular stakeholder group.

\subsection{Hypotheses development}

\subsubsection{Foreign ownership and CSR expenditure}

Foreign owners are from different cultures and geographies and hold different values and knowledge that help promote more CSR expenditure. Moreover, foreign shareholders are more aware of regulation and reputation; therefore, they are most likely to contribute to social awareness programs (Khan et al., 2013). Foreign ownership also 
enhances the visibility of firms to different market forces because of positive influences on corporate governance. Foreign investors are perceived to have greater aptitude and capability to run businesses, relying on creativity, technology, excellent management experience, and inventive ideas to turn them around (Al-Gamrh et al., 2020). Prior research has found an association between foreign ownership and CSR disclosure performance that is positive and significant (Al-Gamrh et al., 2020; Oh et al., 2011; Khan et al., 2013). Masud et al. (2018a) and Bae et al. (2018) found a favorable and substantial association between foreign ownership and the environmental performance of South Asian countries. Furthermore, Jahid et al. (2020) and Khan et al. (2013) found a link between foreign ownership and CSR disclosure of Bangladeshi listed companies. They came to the conclusion that foreign shareholders are more positive when it comes to CSR. However, Khan et al. (2021) recorded no association between foreign investors and sustainability disclosure of Bangladeshi firms. Based on the theoretical discussion and literature review, the study proposes the following hypothesis.

H1: CSR expenditure is positively and significantly associated with foreign ownership.

\subsubsection{Institutional ownership and CSR expenditure}

Institutional owners are considered powerful controllers in the corporate governance elements because they hold a large part of the share (Rashid et al., 2020). Institutional investors can influence CSR investment decisions because of voting power as well as expert resources. Normally, institutional investors intended a long-time investment horizon that motivates CSR expenditure. Erhemjamts and Huang (2019) documented that the longer period investment nature of institutions promotes CSR that increases shareholder value. It is also mentionable that institutional investors have a very strong business background and experiences in the industry that motivates them to establish a long-term relationship with the stakeholders. Prior literature also argued that the institutional leadership style also explores CSR performance because of institutional strategic and responsible leadership. Prior studies of Oh et al. (2011), Masud et al. (2018a), and Bae et al. (2018) documented a positive relationship between institutional shareholders and CSR performance.

Moreover, prior literature also argued that in the absence of long-term investment instruments in the emerging economy, institutional investors may be reluctant to promote CSR performance (Rashid, 2021). The most recent study of Al-Gamrh et al. (2020), Khan et al. (2021), and Bose et al. (2020b) documented no relationship between institutional ownership and CSR expenditure, while Rashid and Hossain (2021) documented a positive and significant association between institutional ownership and CSR disclosure. They argued that institutions own a major amount of a company's total shares; institutional shareholders try to exert control over managers by using various disclosure tactics, which puts enormous pressure on bank management to promote CSR and leads to greater CSRD. Therefore, based on the theoretical discussion and literature review, the study set the following hypothesis.

H2: CSR expenditure is positively and significantly associated with institutional ownership.

\subsubsection{Director ownership and CSR expenditure}

Directors of a firm are mandated for key decisions in the business; therefore, they have active and influential access to the investment decision. Moreover, directors have agency conflict with the owners, so that they like to show business performance in the short term (Khan et al., 2013; Oh et al., 2011). In the changing business environment, directors are facing different types of pressures from the stakeholders' group; as a result, they are interested in investing in CSR projects to mitigate internal and external conflicts. Director shareholding encourages management for more CSR expenditure and activities because of managerial reputation. CSR expenditure enhances corporation visibility because shareholding directors are more communicative, energetic, and ambitious about financial, social, and environmental performance. Moreover, they transfer many responsibilities to resourceful and capable personnel (Oh et al., 2011). Director shareholding plays an active role in promoting social and environmental issues to gain stakeholder attention 
(Khan et al., 2013). Jia and Zhang (2012) documented two reasons for promoting CSR by the director ownership, including risk-taking behavior by the manager and credible signal to the external shareholder. Further, a prior study also argued that holding managerial shares, directors would be reluctant to promote CSR because they will play a vital role in decision-making. It is also considered that managers (agents) will work for their benefits rather than owners (principal) or stakeholders because of the long-term nature of CSR benefits (Masud et al., 2018a).

Prior studies reported mixed results between CSR performance and managerial ownership. Jia and Zhang (2012), and C.-Y. Huang and S. W.-L. Huang (2009) reported a positive and significant relationship between CSR performance and director ownership because of reducing agency conflicts. Bae et al. (2018), Masud et al. (2018), Oh et al. (2011), and Khan et al. (2013) reported a negative and significant relationship between CSR performance and director ownership. Goergen and Renneboog (2010), Li and Zhang (2010) reported a non-significant relationship between CSR performance and director ownership.

Based on the literature review, a few studies considered the impact of actual CSR expenditure on corporate governance. To investigate the research question based on the literature gap, the goal of the study is to see how much ownership structure affects CSR spending. To the best of the authors' knowledge, this is the first study that is considering CSR expenditure to evaluate the relationship between ownership structure and CSR expenditure. Based on the theoretical discussion and literature review, the following hypothesis is proposed:

H3: CSR expenditure is positively and significantly associated with director ownership.

\section{METHODOLOGY}

\subsection{Sample selection}

The study considered financial institutions listed on the Dhaka Stock Exchange covering a period of 2007-2019 years. DSE has 53 listed financial firms (30 banks and 23 non-banks). The study used secondary data sources to collect dependent and independent variables. Annual reports of financial firms are considered to manage financial data sources. On the other hand, CSR data is gathered from the Bangladesh Bank (BB, the central bank of Bangladesh) published reports. BB quarterly published CSR reports of the financial sector. Previous research has shown that the annual report is a more reliable source for measuring corporate governance and CSR data (Khan et al., 2021; Bose et al., 2020a, 2020b; Masud et al., 2018a).

The study selected 2007 to 2019 as the sample year. From the year 2007, BB first published Banking firms' CSR data. Moreover, BB promulgated CSR regulation in 2008 and mandated tax rebates on CSR expenditure (Masud et al., 2018a; Bose et al., 2020b). From the year 2012, BB also published non-banking firms' CSR data. Therefore, the study has incorporated all CSR expenditure data from the beginning (2007) to the end (2019) for a most credible result. From the beginning, the study has documented 574 observations during the study period. Later, missing financial and non-financial data were deducted, including CSR data, ownership data, and financial data. Finally, the study managed 461 firmyear observations. Therefore, the study collected all 53 financial firms' 461 firm-year observations for the last thirteen years (Table 1).

Table 1. Sample selection

\begin{tabular}{c|c:c}
\hline Year & $\begin{array}{c}\text { Total } \\
\text { financial firms }\end{array}$ & $\begin{array}{c}\text { Actual } \\
\text { observations }\end{array}$ \\
\hline 2007 & 30 & 07 \\
\hline 2008 & 30 & 05 \\
\hline 2009 & 30 & 14 \\
\hline 2010 & 30 & 30 \\
\hline 2011 & 30 & 30 \\
\hline 2012 & 53 & 47 \\
\hline 2013 & 53 & 50 \\
\hline 2014 & 53 & 49 \\
\hline 2015 & 53 & 49 \\
\hline 2016 & 53 & 48 \\
\hline 2017 & 53 & 46 \\
\hline 2018 & 53 & 46 \\
\hline 2019 & 53 & 4 \\
\hline Total & 53 & 4 \\
\hline
\end{tabular}


Table 2. Variable definitions and measurements

\begin{tabular}{|c|c|c|c|}
\hline Variables & Ab. form & Exp. sign & Measurements \\
\hline \multicolumn{4}{|r|}{ Dependent variable } \\
\hline CSR expenditure & CSRE & + & $\begin{array}{l}\text { CSRE was measured as a ratio of total CSR expenditure scaled by total } \\
\text { revenue. }\end{array}$ \\
\hline \multicolumn{4}{|r|}{ Independent variables } \\
\hline \multicolumn{4}{|r|}{ Ownership structure } \\
\hline Foreign ownership & FRNO & + & Percentage of shares held by foreign investors \\
\hline Institutional ownership & INSO & + & Percentage of shares held by institutional investors \\
\hline Director ownership & DRTO & $+/-$ & Percentage of shares held by insider directors \\
\hline \multicolumn{4}{|r|}{ Control variables } \\
\hline Board size & $\mathrm{BSIZE}$ & + & Percentage of total directors sit on the board \\
\hline Independent director & IND & + & Total Independent directors are scaled by total directors \\
\hline Firm size & FSIZE & + & Log of total assets of the individual firm \\
\hline Return on assets & ROA & $+/-$ & Net income divided by total assets \\
\hline Leverage & LEV & - & Total debt divided by total assets \\
\hline Advertising expenditure & ADV & + & Log of Advertisement expenses divided by total assets \\
\hline Age & AGE & + & Log of the total number of years in business \\
\hline Year dummy & YD & - & Year dummy was created for twelve years. \\
\hline
\end{tabular}

\subsection{Variable measurement}

\subsubsection{Dependent variable}

The study used CSR expenditure (CSRE) as a dependent variable to find the impact of ownership structures on it. Bangladesh Bank (BB) guided eight areas, including education, healthcare, climate risk management, environment, income-generating activities, infrastructure, cultures and others for the financial sector to spend money as CSRE. The prior studies extensively used CSR disclosure and CSR rating to measure CSR performance (Masud et al., 2017, 2018a, 2019; Bae et al., 2018, Khan et al., 2013, Jahid et al., 2020; Oh et al., 2011). Disclosure-based CSR performance failed to capture the corporation's actual commitment and contribution to CSR activities (Bose et al., 2020b). Prior studies also criticized that content-based disclosure studies only considered either reported or do not report information in the line of guided agendas (Bose et al, 2020b; Abeysekera, 2014). Moreover, non-financial or non-monetary-based information is unable to predict actual benefits driven from financial or monetary activities. Thus, actual CSR expenditure activities can show a firm's real achievement and commitment to these activities (Bose et al., 2020b). The study likes to argue that CSR expenditure vividly explains the motive of the management to use money in this area. Following the study of Khan et al. (2021), Bae et al. (2021), Bose et al. (2020b), and Bhattacharyya and Rahman (2020), the study incorporated CSRE to explore the research goals. To measure the CSRE ratio, the study scaled total CSR expenditure by total revenue. CSRE data is managed from BB's quarterly published report.

\subsubsection{Independent variables}

The study used different corporate governance elements as independent variables, including ownership structure. The study used foreign ownership (FRWO), institutional ownership (INSO), and director ownership (DRTO) following the studies by Jahid et al. (2020), Masud et al. (2018a, 2019), and Bae et al. (2018). The definition and measurement of corporate governance data are presented in Table 2.

\subsubsection{Control variables}

This study used several control variables, including board size (BSIZE), independence director (IND), firm size (FSIZE), firm age (AGE), profitability (ROA), leverage (LEV), and advertising expenditure (ADV) following Bae et al. (2021), Bose et al. (2020a), Jahid et al. (2020), Masud et al. (2019), Khan et al. (2013), and Oh et al. (2011). In addition, certain alternative variables were employed to test the study's robustness. The measurement of all variables is given in Table 2 .

\subsubsection{Data estimation model}

The study used unbalanced panel data. As the data of this study are static in nature, general regres- 
Table 3. Descriptive statistics

\begin{tabular}{|c|c|c|c|c|c|c|c|}
\hline Variable & Obs. & Mean & Std. dev. & Min & Max & Q1 & Q3 \\
\hline CSRE & 461 & 0.005 & 0.006 & 0.000 & 0.021 & 0.001 & 0.007 \\
\hline FRNO & 461 & 3.311 & 7.714 & 0.000 & 29.100 & 0.000 & 1.380 \\
\hline INSO & 461 & 16.812 & 9.705 & 0.000 & 35.100 & 10.000 & 22.630 \\
\hline DRTO & 461 & 38.566 & 15.487 & 5.920 & 62.330 & 30.080 & 49.410 \\
\hline$B S I Z E$ & 461 & 13.004 & 3.548 & 7.000 & 20.000 & 11.000 & 15.000 \\
\hline IND & 461 & 0.167 & 0.088 & 0.000 & 0.333 & 0.118 & 0.214 \\
\hline FRND & 461 & 0.228 & 0.550 & 0.000 & 2.000 & 0.000 & 0.000 \\
\hline$R O A$ & 461 & 0.011 & 0.006 & 0.001 & 0.026 & 0.007 & 0.015 \\
\hline$R O E$ & 461 & 0.052 & 0.053 & 0.002 & 0.163 & 0.010 & 0.097 \\
\hline LEV & 461 & 0.898 & 0.049 & 0.750 & 0.950 & 0.890 & 0.929 \\
\hline FSIZE & 461 & 25.138 & 1.211 & 22.828 & 26.641 & 24.110 & 26.150 \\
\hline$A D V$ & 461 & 16.947 & 1.587 & 13.921 & 19.289 & 15.860 & 18.084 \\
\hline$A G E$ & 461 & 22.000 & 8.590 & 9.000 & 47.000 & 16.500 & 26.500 \\
\hline
\end{tabular}

Note: Variable definitions and measurements are given in Table 2.

sion analysis fits best to estimate the relationship between CSRE and ownership structure. To analyze the link between the dependent and independent variables, the ordinary least square (OLS) regression model was utilized. Moreover, the study checked the fixed or random effect model by using the Hausman test. Hausman's test results provided that the fixed effects model runs at a $1 \%$ level of significance. The estimated OLS model is as follows:

$$
\begin{aligned}
& \operatorname{CSRE}_{i t}=\alpha_{0}+\beta_{1} F R N O_{i t}+\beta_{2} I N S O_{i t}+ \\
& +\beta_{3} D_{R T O}+\beta_{4} B S I Z E_{i t}+\beta_{5} I N D_{i t}+ \\
& \beta_{6} \text { FSIZE }_{i t}+\beta_{7} A G E_{i t}+\beta_{8} R O A_{i t}+ \\
& +\beta_{9} L E V_{i t}+\beta_{10} A D V_{i t}+ \\
& +\beta_{11} Y E A R D U M M Y_{i t}+\varepsilon_{i t},
\end{aligned}
$$

where CSRE $=$ a ratio of corporate social responsibility expenditure scaled by total revenue by each sample firm; $\alpha_{0}=$ the constant; $\varepsilon_{i t}=$ error terms; $\beta_{1}$ to $\beta_{11}=$ the coefficients of the variables defined in Table 1 , and ' $i$ ' and ' $t$ ' $=$ the number of banks and periods, respectively.

\section{EMPIRICAL RESULTS}

\subsection{Descriptive statistics}

The mean and standard divisions (SD) are used to measure the overall performance of Bangladeshi listed financial institutions. Table 3 presents the descriptive data of the sample organizations. The CSRE has a mean of 0.005 , which indicates sample firms spend on average one to two percent of total revenues as CSRE. CSR expenditure of financial firms is different from each other and CSRE is very limited in amount. Among the ownership structure, most of the shares are controlled by the directors as the percentage of their shareholding is 38.57 percent, while institutional and foreign ownership is 16.81 percent and 3.31 percent, respectively. There is a substantial possibility that directors can influence the board in all decision-making. The average board size is 13 percent, where the average size of independent and foreign directors is 0.17 and 0.23 , respectively.

\subsection{Correlations matrix}

The correlation coefficient between any pair of variables utilized in this investigation is shown in Table 4. It shows whether the correlation between the variables is substantial in a negative or positive way. Table 4 shows that CSRE is positively and significantly associated with directors' ownership, the board size, independent directors, firm size, leverage, and advertising expense. On the contrary, CSRE is negatively significant to ROA; it indicates higher financial performance, lower contribution to CSRE. These results may help in further regression analysis.

\subsection{Bivariate analysis}

Multicollinearity is a critical issue to verify the correctness of a model, since one predictor variable in 
Table 4. Correlations matrix

\begin{tabular}{|c|c|c|c|c|c|c|c|c|c|c|c|}
\hline Variable & CSRE & FRNO & INSO & DRTO & BSIZE & IND & FSIZSE & ROA & LEV & ADV & AGE \\
\hline CSRE & 1 & - & - & - & - & - & - & - & - & - & - \\
\hline FRNO & 0.067 & 1 & - & - & - & - & - & - & - & - & - \\
\hline INSO & -0.072 & $-0.178^{* * *}$ & 1 & - & - & - & - & - & - & - & - \\
\hline DRTO & $0.198^{* * *}$ & $-0.094^{* *}$ & $-0.150^{* * *}$ & 1 & - & - & - & - & - & - & - \\
\hline BSIZE & $0.209^{* * *}$ & $-0.180^{* * *}$ & -0.007 & 0.037 & 1 & - & - & - & - & - & - \\
\hline IND & $0.088^{*}$ & $0.189^{* * *}$ & $0.104^{* *}$ & $0.120^{* * *}$ & $-0.395^{* * *}$ & 1 & - & - & - & - & - \\
\hline FSIZE & $0.483^{* * *}$ & $-0.103^{* *}$ & 0.028 & $-0.164^{* * *}$ & $0.353^{* * *}$ & -0.076 & 1 & - & - & - & - \\
\hline ROA & $-0.129^{* * *}$ & $0.168^{* * *}$ & $-0.150 * * *$ & -0.055 & 0.006 & $-0.182^{* * *}$ & $-0.252^{* * *}$ & 1 & - & - & - \\
\hline LEV & $0.353^{* * *}$ & $-0.154^{* * *}$ & 0.046 & 0.015 & $0.177^{* * *}$ & $-0.124^{* * *}$ & $0.625^{* * *}$ & $-0.419^{* * *}$ & 1 & - & - \\
\hline ADV & $0.225^{* * *}$ & -0.003 & $-0.168^{* * *}$ & 0.018 & $-0.100^{* *}$ & $-0.124^{* * *}$ & $0.158^{* * *}$ & 0.064 & $0.157^{* * *}$ & 1 & - \\
\hline AGE & -0.075 & $0.110^{* *}$ & $0.118^{* *}$ & $-0.490^{* * *}$ & 0.013 & $0.092^{* *}$ & $0.307^{* * *}$ & $-0.178^{* * *}$ & 0.037 & 0.054 & 1 \\
\hline
\end{tabular}

Note: Variable definitions and measurements are given in Table $2 .{ }^{*} p<0.10,{ }^{* *} p<0.05$, and ${ }^{* * *} p<0.01$.

a multiple regression model might linearly predict others. When the correlation coefficient between any two variables exceeds 0.90 , it becomes an issue (Black et al., 2010). The strongest correlation coefficient in this study is between business size and leverage; it is 0.625 , which is less than 0.90 , as shown in Table 4. As a result, there is no concern with multicollinearity in this study. In addition, the study used the variance inflation factor (VIF) test to see if the model has a collinearity problem. Table 5 shows that all values below the threshold of 10 indicate that there is no multicollinearity among the variables in the study (Hair et al., 1995).

\subsection{Regression results}

The association between ownership structure and CSRE performance is seen in Table 5. Static models such as pooled OLS, fixed effect, and random effect models were used in the study. The explanatory variables explained nearly $44 \%$ of the variation in the dependent variable "CSR expenditure," according to the adjusted coefficient of determination (Adj. $\mathrm{R}^{2}$ ). The study can take the unmistakable conclusion that this empirical model fits the data well as the p-value of the F-test is statistically significant $(17.37, \mathrm{p}<0.01)$. The pooled OLS model shows a statistically significant impact of ownership structure on CSRE performance. However, endogeneity in ownership pattern is not a concern for Asian firms; Bangladeshi firms are relatively stable over time. Additionally, the present study has used the year dummy to deal with the heterogeneity issue by using year-fixed effects.

Table 5 presents the regression result of the study. The study finds that FRNO is positively and signif- icantly associated with CSRP $(\mathrm{p}<0.01)$. Therefore, $\mathrm{Hl}$ is accepted and the result is consistent with the studies by Masud et al. (2018a), Bae et al. (2018), Khan et al. (2013), and Oh et al. (2011). The result implies that the higher the percentage of foreign ownership, the greater the extent of CSR expenditure. Therefore, the banks are suggested to invite more shareholders from foreigners. As foreign shareholders are more sincere to protect the stakeholder interests, they are more intended to create pressure on the firm management to invest more in CSR functions. On the other hand, the study found an insignificant association between INSO and CSRE. Hence, the study rejects $\mathrm{H} 2$ and the result is consistent with the studies by Khan et al. (2020), Bose et al. (2020), and Al-Gamrh et al. (2020). Bose et al.'s (2020b) study of CSR expenditure and market value found no association between higher CSRE and institutional ownership of Bangladeshi banks also supports the findings. Moreover, a recent study by Khan et al. (2021) also documented no association between sustainability quality reporting and institutional ownership of Bangladeshi banking firms. The result is contradictory but convincing in the context of an emerging economy because emerging economies like Bangladesh have no a long-term pension fund and sufficient mutual fund for institutional investors (Rashid, 2021). The results provide an insight that institutional owners do not influence CSR expenditure. Since institutional owners are more firm productivity-oriented than other owners in Bangladesh (Rashid et al., 2020), they may be reluctant in contributing to CSR investment. It is also mentionable that INSO average shareholding is about 17 percent that is difficult to influence controlling investors. Prior studies pointed to less 
Table 5. Regression results

\begin{tabular}{|c|c|c|c|c|c|}
\hline \multirow{2}{*}{ Variable } & \multirow{2}{*}{ Exp. sign } & OLS regression & Fixed effect & Random effect & \multirow{2}{*}{ VIF } \\
\hline & & CSRE & CSRE & CSRE & \\
\hline \multirow{2}{*}{ FRNO } & \multirow{2}{*}{+} & $0.00013^{* * *}$ & $0.00013^{* * *}$ & $0.00011^{* * *}$ & \multirow{2}{*}{1.17} \\
\hline & & $(0.00003)$ & $(0.00003)$ & $(0.00003)$ & \\
\hline \multirow{2}{*}{ INSTO } & \multirow{2}{*}{+} & 0.00001 & 0.00001 & -0.00001 & \multirow{2}{*}{1.14} \\
\hline & & $(0.00002)$ & $(0.00002)$ & $(0.00002)$ & \\
\hline \multirow{2}{*}{ DRTO } & \multirow{2}{*}{$+/-$} & $0.00007^{* * *}$ & $0.00007^{* * *}$ & $0.00006^{* * *}$ & \multirow{2}{*}{1.49} \\
\hline & & $(0.00002)$ & $(0.00002)$ & $(0.00002)$ & \\
\hline \multirow{2}{*}{ BSIZE } & \multirow{2}{*}{+} & $0.00024^{* * *}$ & $0.00025^{* * *}$ & $0.00022^{* * *}$ & \multirow{2}{*}{1.51} \\
\hline & & $(0.00007)$ & $(0.00007)$ & $(0.00007)$ & \\
\hline \multirow{2}{*}{ IND } & \multirow{2}{*}{+} & $0.01657^{* * *}$ & $0.01783^{* * *}$ & $0.01097^{* * *}$ & \multirow{2}{*}{1.45} \\
\hline & & $(0.00320)$ & $(0.00322)$ & $(0.00282)$ & \\
\hline \multirow{2}{*}{ FSIZE } & \multirow{2}{*}{+} & $0.00235^{* * *}$ & $0.00241^{* * *}$ & $0.00231^{* * *}$ & \multirow{2}{*}{2.24} \\
\hline & & $(0.00025)$ & $(0.00025)$ & $(0.00025)$ & \\
\hline \multirow{2}{*}{$R O A$} & \multirow{2}{*}{$+/-$} & $-0.09193^{* *}$ & $-0.09868^{* *}$ & -0.02142 & \multirow{2}{*}{1.44} \\
\hline & & $(0.04027)$ & $(0.04007)$ & $(0.03855)$ & \\
\hline \multirow{2}{*}{ LEV } & \multirow{2}{*}{-} & -0.00360 & -0.00530 & 0.00324 & \multirow{2}{*}{2.12} \\
\hline & & $(0.00614)$ & $(0.00614)$ & $(0.00606)$ & \\
\hline \multirow{2}{*}{$A D V$} & \multirow{2}{*}{+} & $0.17184^{* * *}$ & $0.16814^{* * *}$ & $0.19405^{* * *}$ & \multirow{2}{*}{1.16} \\
\hline & & $(0.03974)$ & $(0.03953)$ & $(0.04112)$ & \\
\hline \multirow{2}{*}{$A G E$} & \multirow{2}{*}{+} & $-0.00261^{* * *}$ & $-0.00233^{* * *}$ & $-0.00321^{* * *}$ & \\
\hline & & $(0.00078)$ & (0.00078) & $(0.00076)$ & 1.60 \\
\hline Year & my & & & & \\
\hline Constant & & $-0.05086^{* * *}$ & $-0.05312^{* * *}$ & $-0.05431^{* *}$ & \\
\hline$(0.00600)$ & & $(0.00582)$ & $(0.00576)$ & & \\
\hline F-statistics & & $17.36733^{* * *}$ & $33.69531^{* * *}$ & - & - \\
\hline$R^{2}$ & & 0.46591 & 0.43480 & - & - \\
\hline Adj. $R^{2}$ & & 0.43908 & 0.40642 & - & \\
\hline Observations & & 461 & 461 & 461 & \\
\hline
\end{tabular}

Note: Variable definitions and measurements are given in Table 2. Standard errors in parentheses. ${ }^{*} p<0.10,{ }^{* *} p<0.05$, and ${ }^{* * *} p<0.01$

than 50 percent of shareholding investors being unable to influence firm performance positively (Al-Gamrh et al., 2020).

In the ownership structure, the last variable is DRTS, which is positively and significantly associated with CSRP $(p<0.01)$. Hence, the study accepts $H 3$, and the result is supported by the studies of Jahid et al. (2020), Jia and Zhang (2012), and C.-Y. Huang and S. W.-L. Huang (2009). Higher managerial ownership reduces agency cost and encourages management to invest more in CSR expenditure because of managerial and corporate reputation (Bingham et al., 2011), closely tied to the firm as a general shareholder (Goergen \& Renneboog 2010), encourages strict monitoring and controlling to any socially irresponsible investment and behavior (Goergen \& Renneboog, 2010), and creates opportunities to establish business goals (Li \& Zhang, 2010). The study documented that the average DRTO share is 39 percent that can control the investment decision over CSR expenditure. Moreover, prior studies also argued that higher shareholding by the director reduces CSR performance because of time horizon, personal interests, and lack of stakeholder engagement (Dam \& Scholtens 2013). Hence, the study tends to believe that more DRTO helps management consider CSRE as a strategic issue rather than philanthropic that will carry more opportunities and eliminate possible threats. CSR expenditure is a very new concept in Bangladesh, which enjoys 
limited social and institutional pressures (Khan et al., 2021; Bose et al., 2020b). Therefore, at this moment, it is required to establish strict monitoring and controlling mechanisms that can be done easily by managerial investors. The result implies that the greater the percentage of director shareholders, the higher the level of CSR expenditure. The result is also consistent with the recent CSR expenditure study by Bose et al. (2020b), while they argued that higher CSR expenditure increases higher financial performance.

The study also considered a set of control variables, and the results indicate that BSIZE, IND, FSIZE and ADVE are positively and significantly related with CSR expenditure $(p<0.01)$, and the result is followed by Masud et al. (2018), Bae et al. (2018), Khan et al. (2013), and Oh et al. (2011). Moreover, ROA and AGE are negatively and significantly associated with CSRE, while LEV has no association.

\subsection{Robustness tests}

To prove the authenticity, the study incorporated additional sensitivity analysis. If the main OLS (Table 5) result is similar to the additional analysis (Table 6), the findings are robust. For robustness check, the study used alternative variables both for dependent and independent variables. First, the study used an alternative dependent variable measured as a ratio of total CSR expenditure scaled by total assets (column 2) and found simi-

Table 6. Sensitivity analysis

\begin{tabular}{|c|c|c|c|c|}
\hline Variable & CSRE/Assets & $F R N O=F R N D$ & $R O A=R O E$ & FSIZE = Revenue \\
\hline \multirow{2}{*}{ FRNO } & $0.00001^{* * *}$ & - & $0.00013^{* * *}$ & $0.00012^{* * *}$ \\
\hline & $(0.00000)$ & - & $(0.00003)$ & $(0.00003)$ \\
\hline \multirow{2}{*}{ INSTO } & -0.00001 & 0.00001 & 0.00001 & 0.00001 \\
\hline & $(0.00001)$ & $(0.00002)$ & $(0.00002)$ & $(0.00002)$ \\
\hline \multirow{2}{*}{ DRTO } & $0.00001^{* * *}$ & $0.00007^{* * *}$ & $0.00008^{* * *}$ & $0.00007^{* * *}$ \\
\hline & $(0.00000)$ & $(0.00002)$ & $(0.00002)$ & $(0.00002)$ \\
\hline \multirow{2}{*}{$B S I Z E$} & $0.00002^{* * *}$ & $0.00024^{* * *}$ & $0.00023^{* * *}$ & $0.00026^{* * *}$ \\
\hline & $(0.00001)$ & $(0.00007)$ & $(0.00007)$ & $(0.00007)$ \\
\hline \multirow{2}{*}{ IND } & $0.00136^{* * *}$ & $0.01768^{* * *}$ & $0.01649^{* * *}$ & $0.01716^{* * *}$ \\
\hline & $(0.00025)$ & $(0.00315)$ & $(0.00320)$ & $(0.00328)$ \\
\hline \multirow{2}{*}{ FSIZE } & $0.00018^{* * *}$ & $0.00248^{* * *}$ & $0.00221^{* * *}$ & - \\
\hline & $(0.00002)$ & $(0.00025)$ & $(0.00025)$ & - \\
\hline \multirow{2}{*}{$R O A$} & -0.00482 & $-0.08039^{* *}$ & - & $-0.12155^{* * *}$ \\
\hline & $(0.00319)$ & $(0.03958)$ & - & $(0.04175)$ \\
\hline \multirow{2}{*}{ LEV } & -0.00017 & -0.00552 & 0.00193 & 0.00128 \\
\hline & $(0.00049)$ & $(0.00610)$ & $(0.00553)$ & $(0.00625)$ \\
\hline \multirow{2}{*}{$A D V$} & $0.01232^{* * *}$ & $0.15616^{* * *}$ & $0.16778^{* * *}$ & $0.18963^{* * *}$ \\
\hline & (0.00315) & (0.03947) & (0.03971) & $(0.04054)$ \\
\hline \multirow{2}{*}{$A G E$} & $-0.00027^{* * *}$ & $-0.00291^{* * *}$ & $-0.00233^{* * *}$ & $-0.00210^{* * *}$ \\
\hline & $(0.00006)$ & $(0.00078)$ & $(0.00077)$ & $(0.00079)$ \\
\hline \multirow{2}{*}{$R O E$} & & & $-0.01000^{* *}$ & - \\
\hline & & & $(0.00495)$ & - \\
\hline \multirow{2}{*}{ REVENUE } & & & - & $0.00212^{* * *}$ \\
\hline & & & - & $(0.00026)$ \\
\hline \multirow{2}{*}{ FRND } & - & $0.00197^{* * *}$ & - & - \\
\hline & - & $(0.00037)$ & - & - \\
\hline Year dummy & \multicolumn{4}{|c|}{ Included } \\
\hline \multirow[t]{2}{*}{ Constant } & $-0.00373^{* * *}$ & $-0.05098^{* * *}$ & $-0.05414^{* * *}$ & $-0.04557^{* * *}$ \\
\hline & $(0.00048)$ & $(0.00596)$ & $(0.00552)$ & $(0.00604)$ \\
\hline Observations & 461 & 461 & 461 & 461 \\
\hline F-statistics & $15.14667 * * *$ & $17.94084^{* * *}$ & $17.27293^{* * *}$ & $15.62157^{* * *}$ \\
\hline$R^{2}-1$ & 0.43207 & 0.47400 & 0.46455 & 0.43966 \\
\hline Adj. $R^{2}$ & 0.40355 & 0.44758 & 0.43766 & 0.41152 \\
\hline
\end{tabular}

Note: FRND presents the number of foreigners on the board; REVENUE indicates the log of total revenues of the individual firm; $R O E$ represents net income divided by total equity. Standard errors in parentheses; ${ }^{*} p<0.10,{ }^{* *} p<0.05$, and ${ }^{* * *} p<0.01$. 
lar results to the baseline model. Second, the study took FRND as an alternative proxy of FRNO (column 3) and reported a positive and significant association $(p<0.01)$, which is also similar to the baseline model. Third, the study considered $R O E$ as an alternative proxy of $R O A$ (column 3) and documented similar findings of the baseline model. Finally, the study replaced firm REVENUE instead of FSIZE, and the results remain unchanged. Additionally, every model's results are in line with the baseline model that proves the study as robust.

\section{DISCUSSION}

CSRE is considered a crucial corporate management mechanism to support sustainability performance and value creation. BB's environmental and CSR policies and regulations have influenced the banking sector to become a sustainable leader. As a result, from 2010 to 2019, the financial industry spent more than doubled its CSR activities. The study chose financial organizations from 2007 to 2019 to investigate the elements that determine the impact of corporate governance on CSR expenditure. The prior literature suggested that the institutional regulatory environment and stakeholder engagement could better explain CSRE and ownership.

The study tested ownership structure variables, and the result pointed out that the nature of CSR expenditure of the country's financial sector firms majorly depends on the corporate governance elements. The study reported that foreign shareholding significantly influenced more CSR expenditure. The study believes that cultural differences, best industry practice experience, and more ingrained attitudes influence foreign investors to take positive action of higher CSR expenditure. Moreover, a foreign investor likes to share the host country's social and environmental experiences in the new business environment because of engaging stakeholders and creating a positive impression of the business. Bangladesh is an emerging economy, therefore, policymakers and business management should invite more foreign investors to change the prevailing business environment and enjoy competitiveness. On the other hand, the study did not find any significant value of institutional shareholding that is very surprising but consistent with the prior study. Institutional investors invest in the long-run project, but in Bangladesh, long-run business products are absent (Rashid, 2021). It is also noteworthy to mention that the capital and money market of the country is run by short-term investment funds, including mutual funds and superannuation funds (Rashid, 2021). Moreover, the shareholding pattern of institutional investors of the country is minimum, which would be a possible reason for ignoring CSR expenditure. The study also used managerial ownership and found a positive association with CSRE. Directors hold most of the share that makes them controllers of the management and business. A higher shareholding pattern helps them to invest higher CSR expenditure for gaining business reputation, more visibility, and market growth. CSR expenditure helps to create value to the business, therefore director ownership likes to establish strategically CSR in the decision-making for future benefits. Director-owners control the business, therefore, they want to keep the commitment, actual CSR expenditure helps them to revise CSR policy and regulations. Moreover, to check the manager's CSR expenditure function, it is also required to establish a strong regulatory framework because higher shareholding inspires the director to involve political CSR for showing personal power and implementing political party's agenda (Uddin et al., 2016).

\section{CONCLUSION}

The study has significant theoretical and managerial contributions. To the best of the authors' knowledge, this is the first study of the impact of ownership structure on CSR expenditure. Therefore, the study has a significant contribution to corporate governance theory. CSR expenditure can be utilized to measure the performance of the corporate governance element. The monetary nature of CSR function is the new mechanism to evaluate corporate management commitment and performance. Theoretically, the study contributed to the agency cost and stakeholders. Higher CSR expenditure can be engaged to reduce agency conflict because management (agent) will be strictly evaluated by the principal (own- 
er). It will be also very fruitful to the owner to check each monetary CSR function performed by the management (i.e. audited by a third party, assurance statement). On the contrary, stakeholder theory contributes to the stakeholder engagement mechanism through CSR expenditure. Different stakeholder groups can scrutinize the actual amount of money used by the name of CSR. Visible CSR expenditure efficiently and effectively communicates between stakeholders and management that will ultimately enhance market reputation, transparency, growth, stability, and performance. Hence, CSRE can be used as an effective mechanism between stakeholders and management for enhancing trust and confidence. Moreover, the study has significant managerial and policy implications. Higher CSRE increases profitability and firm value, therefore, strong regulation is inevitable in this sector. Financial firms are utilizing CSRE for value creation that could be a role model for the non-financial sector. Business management should use the strategic CSR concept rather than philanthropic. Policymakers should promulgate a holistic mandatory strategic CSR framework to all sectorial firms.

Despite significant contributions, the study is not without limitations. Firstly, the study only considered listed financial firms. Secondly, it omitted some influential governance variables and the impact of political CSR expenditure. Thirdly, the study did not incorporate appropriate theoretical setting to best explain corporate governance and CSR expenditure (i.e. organization identity theory). Lastly, the study ignored market-driven variables and organizational regulatory forces. Future studies should incorporate financial and non-financial firms to investigate all corporate governance elements. Moreover, a future study can be taken into consideration to investigate regulatory framework, market forces, and profitability impact on CSR expenditure.

\section{AUTHOR CONTRIBUTIONS}

Conceptualization: Md. Abdul Kaium Masud.

Data curation: Md. Abu Jahid, Md. Harun Ur Rashid.

Formal analysis: Md. Abdul Kaium Masud, Md. Abu Jahid, Md. Harun Ur Rashid.

Funding acquisition: Md. Abdul Kaium Masud, Md. Abu Jahid, Rizal Yaya

Investigation: Md. Abdul Kaium Masud.

Methodology: Md. Abdul Kaium Masud, Md. Abu Jahid, Md. Harun Ur Rashid.

Project administration: Md. Abdul Kaium Masud, Md. Harun Ur Rashid, Rizal Yaya.

Resources: Rizal Yaya.

Software: Md. Harun Ur Rashid.

Supervision: Rizal Yaya.

Writing - original draft: Md. Abdul Kaium Masud, Md. Harun Ur Rashid.

Writing - reviewing \& editing: Md. Abdul Kaium Masud.

\section{ACKNOWLEDGMENT}

Comments and suggestions from the discussants and paper presenters and audiences of International Conference on Sustainable Innovation (ICoSI 2020) at Universitas Muhammadiyah Yogyakarta, Indonesia, have been gratefully acknowledged, which helps us to improve the quality of this paper.

\section{FUNDING}

The research is supported by Noakhali Science and Technology University, Bangladesh and Universitas Muhammadiyah Yogyakarta, Indonesia. 


\section{REFERENCES}

1. Abeysekera, I. (2014). Why Do Firms Disclose and Not Disclose Structural Intangibles? Advances in Accounting, 30(2), 381-93. Retrieved from https://papers.ssrn. $\mathrm{com} / \mathrm{sol} 3 /$ papers.cfm?abstract_ $\mathrm{id}=2531905$

2. Al-Gamrh, B., Al-Dhamari, R., Jalan, A., \& Afshar Jahanshahi, A. (2020). The impact of board independence and foreign ownership on financial and social performance of firms: evidence from the UAE. Journal of Applied Accounting Research, 21(2), 201229. https://doi.org/10.1108/JAAR09-2018-0147

3. Ashwin, A. S., Krishnan, R. T., \& George, R. (2015). Family firms in India: Family involvement, innovation and agency and stewardship behaviors. Asia Pacific Journal of Management, 32(4), 869-900. https://doi.org/10.1007/ s10490-015-9440-1

4. Bae, S. M., Masud, M. A. K, Rashid, M. H, \& Kim, J. D. (2021). Determinants of Climate Financing and the Moderating Effect of Politics: Evidence from Bangladesh. Sustainability Accounting Management and Policy Journal, 13(1), 247-272. https://doi. org/10.1108/SAMPJ-04-2019-0157

5. Bae, S. M., Masud, M. A. K., \& Kim, J. D. (2018). A cross-country investigation of corporate governance and corporate sustainability disclosure: A signaling theory perspective. Sustainability, 10(8), 2611. https:// doi.org/10.3390/su10082611

6. Bhattacharyya, A., \& Rahman, M. L. (2020). Mandatory CSR expenditure and stock return. Meditari Accountancy Research, 28(6), 951-975. https://doi.org/10.1108/MEDAR-10-2019-0591

7. Bingham, J. B., Dyer, W. G., Smith, I., \& Adams, G. L. (2011). A stakeholder identity orientation approach to corporate social performance in family firms. Journal of Business Ethics, 99(4), 565-585. https://doi.org/10.1007/ s10551-010-0669-9
8. Black, W. C., Babin, B. J., \& Anderson, R. E. (2010). Multivariate data analysis: A global perspective. London: Pearson.

9. Bose, S., Khan, H. Z., \& Monem, R. M. (2020a). Does Green Banking Performance Pay Off? Evidence from a Unique Regulatory Setting in Bangladesh. Corporate Governance: An International Review, 29(2), 162187. https://doi.org/10.1111/ corg. 12349

10. Bose, S., Saha, A., \& Abeysekera, I. (2020b). The Value Relevance of Corporate Social Responsibility Expenditure: Evidence from Regulatory Decisions. ABACUS, 56(4), 455-494. https://doi. org/10.1111/abac.12207

11. Dam, L., \& Scholtens, B. (2013). Ownership concentration and CSR policy of European multinational enterprises. Journal of Business Ethics, 118(1), 117-126. https://doi.org/10.1007/s10551012-1574-1

12. Dharmapala, D., \& Khanna, V. (2018). The impact of mandated corporate social responsibility: evidence from India's companies act of 2013. International Review of Law and Economics, 56, 92104. https://doi.org/10.1016/j. irle.2018.09.001

13. Erhemjamts, O., \& Huang, K. (2019). Institutional ownership horizon, corporate social responsibility and shareholder value. Journal of Business Research, 105, 61-79. https://doi. org/10.1016/j.jbusres.2019.05.037

14. Feng, Z. Y., Wang, M. L., \& Huang, H. W. (2015). Equity Financing and Social Responsibility: Further International Evidence. The International Journal of Accounting, 50(3), 247-80. https://doi. org/10.1016/j.intacc.2015.07.005

15. Goergen, M., \& Renneboog, L. (2010). The social responsibility of major shareholders. In G. Aras \& D. Crowther (Eds.), A handbook of corporate governance and social responsibility (pp. 287-305). Farnham, Burlington: Gower.
16. Hair, J., Anderson, R. E., Tatham, R. L., \& Black, W. (1995). Multivariate data analysis with readings. Tulsa, OK: Petroleum Publishing.

17. Harjoto, M., \& Laksmana, I. (2016). The Impact of Corporate Social Responsibility on Risk Taking and Firm Value. Journal of Business Ethics, 151, 353-373. https://doi.org/10.1007/s10551016-3202-y

18. Huang, C.-Y., \& Huang, S. W.-L. (2009). Ownership structure and corporate social performance. Retrieved from http://www.jgbm. org/page/23Wei-Ling\%20Huang. pdf

19. Jahid, A., Rashid, M. H. U., Hossain, S. Z., Haryono, S., \& Jatmiko, B. (2020). Impact of Corporate Governance Mechanisms on Corporate Social Responsibility Disclosure of Publicly-Listed Banks in Bangladesh. The Journal of Asian Finance, Economics and Business, 7(6), 61-71. https://doi. org/10.13106/jafeb.2020.vol7. no6.061

20. Jia, M., \& Zhang, Z. (2012). Managerial Ownership and Corporate Social Performance: Evidence from Privately Owned Chinese Firms' Response to the Sichuan Earthquake. Corporate Social Responsibility and Environmental Management, 20(5), 257-274. https://doi.org/10.1002/ csr. 1289

21. Kapoor, G. K., \& Dhamija, S. (2017). Mandatory CSR spending - Indian experience. Emerging Economy Studies, 3(1), 98-112. https://doi.org/10.1002/bsd2.46

22. Khan, A., Muttakin, M. B., \& Siddiqui, J. (2013). Corporate Governance and Corporate Social Responsibility Disclosures: Evidence from an Emerging Economy. Journal of Business Ethics, 114(2), 207-223. https://doi. org/10.1007/s10551-012-1336-0

23. Khan, H. Z., Bose, S., \& Johns, R. (2020). Regulatory influences on CSR practices within banks 
in an emerging economy: Do banks merely comply? Critical Perspectives on Accounting, 71, 102096. https://doi.org/10.1016/j. сра.2019.102096

24. Khan, H. Z., Bose, S., Mollik, A. T., \& Harun, H. (2021). "Green washing" or "authentic effort"? An empirical investigation of the quality of sustainability reporting by banks. Accounting, Auditing \& Accountability Journal, 34(2), 338-369. https://doi.org/10.1108/ AAAJ-01-2018-3330

25. Li, W., \& Zhang, R. (2010). Corporate social responsibility, ownership structure, and political interference: Evidence from China. Journal of Business Ethics, 96(4), 631-645. https://doi.org/10.1007/ s10551-010-0488-Z

26. Manchiraju, H., \& Rajgopal, S. (2017). Does corporate social responsibility create shareholder value? Evidence from the Indian companies act 2013. Journal of Accounting Research, 55(5), 1257-1300. https://doi. org/10.1111/1475-679X.12174

27. Masud, M. A. K., Bae, S. M., Manzanares, J., \& Kim, J. D. (2019). Board Directors' Expertise and Corporate Corruption Disclosure: The Moderating Role of Political Connections. Sustainability, 11(16), 4491. https://doi.org/10.3390/ su11164491

28. Masud, M. A. K., Nurunnabi, M., \& Bae, S. M. (2018a). The effects of corporate governance on environmental sustainability reporting: empirical evidence from South Asian countries. Asian Journal of Sustainability and Social Responsibility, 3(1), 3. https://doi. org/10.1186/s41180-018-0019-x

29. Masud, M. A. K., Rashid, M. H. U., Khan, T., Bae, S. M., \& Kim, J. D. (2019). Organizational strategy and corporate social responsibility: The mediating effect of triple bottom line. International Journal of Environmental Research and Public Health, 16(22), 4559. https://doi. org/10.3390/ijerph16224559

30. Masud, M., Hossain, M., \& Kim, J. (2018b). Is Green Regulation
Effective or a Failure: Comparative Analysis between Bangladesh Bank (BB) Green Guidelines and Global Reporting Initiative Guidelines. Sustainability, 10(4), 1267. https://doi.org/10.3390/ su10041267

31. Oh, W. Y., Chang, Y. K., \& Martynov, A. (2011). The Effect of Ownership Structure on Corporate Social Responsibility: Empirical Evidence from Korea. Journal of Business Ethics, 104(2), 283-297. https://doi.org/10.1007/ s10551-011-0912-z

32. Rahman, Moh. M., Rahman, Md. M., Rahman, Mah., \& Masud, M. A. K. (2021). The Impact of Trade Openness on the Cost of Financial Intermediation and Bank Performance: Evidence from BRICS Countries. International Journal of Emerging Markets, ahead-of-print. https://doi. org/10.1108/IJOEM-04-2021-0498

33. Rashid, A. (2021). Institutional shareholding and corporate social responsibility reporting: evidence from Bangladesh. Journal of Asia Business Studies, 15(1), 153-173. https://doi.org/10.1108/JABS-092019-0285

34. Rashid, M. H. U., \& Hossain, S. Z. (2021). Does board independence moderate the effect of politician directors on CSR disclosure? Evidence from the publicly listed banks in Bangladesh. Social Responsibility Journal, ahead-ofprint. https://doi.org/10.1108/SRJ08-2020-0320

35. Rashid, M. H. U., Khanam, R., \& Ullah, M. H. (2021). Corporate governance and IFSB standard-4: evidence from Islamic banks in Bangladesh. International Journal of Islamic and Middle Eastern Finance and Management, 15(1), 1-17. https://doi.org/10.1108/ IMEFM-03-2020-0124

36. Rashid, M. H. U., Zobair, S. A. M., Chowdhury, M. A. I., \& Islam, A. (2020). Corporate governance and banks' productivity: evidence from the banking industry in Bangladesh. Business Research, 13, 615-637. https://doi.org/10.1007/ s40685-020-00109-X
37. Uddin, S., Siddiqui, J., \& Islam, M. A. (2018). Corporate Social Responsibility Disclosures, Traditionalism and Politics: A Story from a Traditional Setting. Journal of Business Ethics, 151, 409-428. https://doi.org/10.1007/ s10551-016-3214-7

38. World Bank. (2017). The World Bank in Bangladesh. Overview. Retrieved from http://www.worldbank.org/en/country/bangladesh/ overview 